\title{
Patterns of drug abuse in Upper Egypt: cause or result of violence?
}

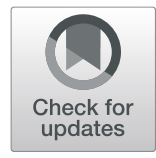

\author{
Heba A. Yassa ${ }^{1^{*}}$ (D) and Shahir T. Badea ${ }^{2}$
}

\begin{abstract}
Background: Drug abuse and violence both are dangerous phenomena in all countries. The relation between drug abuse and violence is obscure, and what comes first is the question. This study clarifies the changes in drug abuse patterns in Upper Egypt and the association between drug abuse and different types of violence.

Method: Three hundred patients seeking medical advice in Mental Health Hospital participated in this study. After obtaining their informed written consent, they underwent urine analysis to determine the abused drug and filled up a questionnaire to determine the type of violence. In this study, the patients were asked to fill out two types of scales: Adolescent Alcohol and Drug Involvement Scale (AADIS) and the Modified Overt Aggression Scale (MOAS).
\end{abstract}

Results: Patterns of drug abuse have been changed in Upper Egypt since the appearance of tramadol. The age of onset of abuse was $17.5 \pm 5.5$ years old. The age of 21-30 years old is the age of adult which is mostly affected. Most of the patients use combination of tramadol and others like alcohol, cannabis, other opioids, but $25 \%$ use tramadol alone. The type of violence changes from one drug abuse to another; auto-aggression was found in cannabis, while aggression towards objects and others was found in tramadol, inhalants, and other opioids.

Conclusion: Drug abuse is a direct cause that increases the violence in the community. Types and degree of violence differ according to the drug abuse type.

Keywords: Addict, Auto aggression, Cannabis, Drug abuse, Inhalants, Tramadol

\section{Background}

Drug abuse is a dangerous phenomenon in all countries. According to the World Drug Report (2017), 29.5 million globally suffer from drug use disorders (World drug report 2017). In Egypt, and since 1970s, there was a sudden increase in numbers of abusers (Hamdi et al. 2016). In Egypt, the first report for prevalence of drug abuse was published in Arabic and proved that $6.2 \%$ of the population declared the use of these substances at least once (Rakhawy et al. 1996) and this continued to increase as reported in Hamdi et al. (2016).

According to the National Institute of Health (NIH), drug abuse comprises three stages: (1) Drug use refers to taking the drug to distinguish it. (2) Drug abuse refers to any harmful use of drugs. Lastly, (3) dependence, refers to substance dependence as defined by the Diagnostic and Statistical manual of Mental Disorders (DSM) or

\footnotetext{
* Correspondence: heba612@hotmail.com; Hebayassa@aun.edu.eg ${ }^{1}$ Forensic Medicine and Clinical Toxicology Department, Assiut University, Asyut, Egypt

Full list of author information is available at the end of the article
}

addiction (Qureshi et al. 2000). Addiction refers to chronic relapsing brain disease that is characterized by drug seeking and re-use even with harmful effects (NIDA 2017). Some researches show that there are some connections between violence, suicidal risk, and substance abuse (Tiet et al. 2006 and Ilgen 2011).

Violence is a complex phenomenon, and WHO has defined it as the intentional use of threatened physical force against oneself, other person, or against a group or community that results in death, injury, maldevelopment, psychological harm, or deprivation (WHO 2002). In 2000, about 1.6 million people worldwide lost their lives due to violence either homicidal or suicidal (WHO 2002). In Egypt, according to the data obtained from the Ministry of Interior, reported homicide cases were 3549 with a rate of $4.34 / 100,000$ in 2011, without causing death and without the suicidal cases (WHO 2014a, b).

According to the media and research studies, violence became a serious problem in most countries (Meyer et al. 2008). Risk factors for violence are complex, and 
many factors may contribute and interact. Researchers conclude a complex relation between violence and drug abuse where many variables can contribute and are difficult to be measured (Boles and Miotto 2003). The aim of this study is to assess the relationship between use of certain type of drug abuse and the type of violence related to it, as well as the degree of violence, and to clarify the patterns of drug abuse in Upper Egypt.

\section{Materials and method Participants}

The study was conducted in addiction clinic, Assiut Mental Health Hospital, during the year of 2017, after the permission of the ethical and research committee of the General Secretarial of Mental Health and Addiction was obtained. Three hundred addicts participated in this study after obtaining their informed consent, with full explanation of the study and its steps. All patients who participated in the study were asked to fill up a questionnaire (Additional files 1, 2 and 3) with the authors' help and gave a urine sample for drug abuse analysis. Complete confidentiality was followed where all data and information either obtained from patients or obtained during interviews were kept as secrets. Questionnaires were maintained by code numbers and not by the patients' names.

\section{Method}

Sociodemographic data and history of addiction were taken using the form prepared for the study. Many variables were included such as age, sex, educational level, residence, age of onset of substance or drug use, and information about the criminal and violence history as seen in Additonal files 1, 2 and 3, using the Modified Overt Aggression Scale (MOAS) and Adolescent
Alcohol and Drug Involvement Scale (AADIS) scales (Kay et al. 1988; and Moberg and Hahn 1991).

Data related to the substance use, amount, method of use, and manner of use were taken from the patients according to the questionnaire and the form in Additional files 1 and 3. Data for the violence and aggression behaviors for the patients before and during addiction were taken according to the MOAS form.

Validation of AADIS form was done by adding the most common drugs used in Egypt (tramadol and bango).

Urine analysis for all patients was done using Multi-Drug Step Screen Test Panel for urine with cutoff value shown in Table 1 to confirm their history about the drug abuse. Immunoassays are tests based upon the ability of the antibody to bind with the drug of abuse (Feldkamp 2010). A qualitative, rapid test includes large-scale screening. The main disadvantage is that false positive results may occur (Wu 2001 and Moller et al. 2008). When a difference was detected between the history and the test, a confirmatory test using high-performance liquid chromatography (HPLC) was used.

Urine specimen validity test criteria were done according to the Mandatory Guidelines for Federal Workplace Drug Testing Program (FR 2017).

\section{Results}

Table 1 shows the cutoff value used in this study according to the kits used in the study, the Multi-Drug One Step Screen Test Panel. The kits can assess amphetamine, barbiturates, benzodiazepines, cocaine, heroin, marijuana, methadone, methamphetamine, methylenedioxymet-amphetamine, morphine, opiates, phencyclidine, tricyclic Antidepressant, and tramadol.

Table 1 The cut off value of the One Step Screen Test panel for urine (according to the kit used)

\begin{tabular}{lll}
\hline Test & Calibrator & Cutoff (ng/ml) \\
\hline Amphetamine (AMP) & d-Amphetamine & 1000 \\
Barbiturates (BAR) & Secobarbital & 300 \\
Benzodiazepines (BZO) & Oxazepam & 300 \\
Cocaine (COC) & Benzoylecgonine & 300 \\
Heroin (HRN) & 6 Acetylmorhine & 10 \\
Marijuana & THC) 11-nor- $\Delta 9$ - THC-9 COOH) & 50 \\
Methadone (MTD) & Methadone & 300 \\
Methamphetamine (mAMP) & d-Methamphetamine & 1000 \\
Methylenedioxymethamphetamine (MDMA) & d,l Methylenediox-ymethamphetamine & 500 \\
Morphine (MOP 300 or OPI 300) & Morphine & 300 \\
Opiates (OPI 2000) & Morphine & 2000 \\
Phencyclidine (PCP) & Phencyclidine & 25 \\
Tricyclic antidepressants (TCA) & Nortriptyline & 1000 \\
Tramadol (TRA) & Tramadol & 100 \\
\hline
\end{tabular}


Table 2 Sociodemographic characteristics of the studied addict patients and the relation to violence within the period of addiction

\begin{tabular}{|c|c|c|c|c|c|c|}
\hline \multirow[t]{2}{*}{ Characteristics } & \multicolumn{4}{|c|}{ Committed violence in period of addiction } & \multicolumn{2}{|c|}{ Analysis } \\
\hline & No. & $\%$ & No. & $\%$ & $\mathrm{df}$ & $P$ \\
\hline \multicolumn{7}{|l|}{ Age } \\
\hline 10 to $\leq 20$ & 32 & 10.7 & 10 & 3.33 & & \\
\hline 21 to $\leq 30^{*}$ & $175^{*}$ & $58.3^{*}$ & $105^{*}$ & $35^{*}$ & 1 & $0.05^{*}$ \\
\hline 31 to $\leq 40$ & 75 & 25 & 55 & 18.3 & & \\
\hline 41 to $\leq 50$ & 18 & 6 & 7 & 2.33 & & \\
\hline \multicolumn{7}{|l|}{ Sex } \\
\hline Males & 295 & 98.3 & 175 & 58.33 & 1 & $0.001^{* *}$ \\
\hline Females & 5 & 1.7 & 2 & 0.66 & & \\
\hline \multicolumn{7}{|l|}{ Education } \\
\hline University & 52 & 17.3 & 32 & 10.6 & & \\
\hline Secondary school & 100 & 33.4 & 60 & 20 & 2 & n.s \\
\hline Primary school & 45 & 15 & 28 & 9.33 & & \\
\hline Illiterate & 103 & 34.3 & 57 & 19 & & \\
\hline \multicolumn{7}{|l|}{ Marital status } \\
\hline Married & 102 & 34 & 53 & 17.66 & & \\
\hline Not married & 134 & 44.7 & 72 & 24 & 2 & n.s. \\
\hline Separate/divorced & 64 & 21.3 & 52 & 17.33 & & \\
\hline \multicolumn{7}{|l|}{ Residence } \\
\hline Rural & 147 & 49 & 86 & 28.66 & 2 & n.s \\
\hline Urban & 153 & 51 & 91 & 30.33 & & \\
\hline \multicolumn{7}{|l|}{ Occupation } \\
\hline Unemployed & 75 & 25 & 45 & 15 & & \\
\hline Student & 102 & 34 & 54 & 18 & 2 & n.s \\
\hline Regular work & 66 & 22 & 37 & 12.33 & & \\
\hline Irregular work & 57 & 19 & 41 & 13.66 & & \\
\hline \multicolumn{7}{|l|}{ Be a previous victim } \\
\hline Yes & 78 & 26 & 73 & 24.33 & 1 & $0.001^{* *}$ \\
\hline No & 222 & 74 & 104 & 34.66 & & \\
\hline \multicolumn{7}{|l|}{ Duration of addiction } \\
\hline Less than 1 year & 17 & 5.7 & 6 & 2 & & \\
\hline $1-5$ years & 62 & 20.7 & 37 & 12.33 & 1 & $0.001^{* *}$ \\
\hline $5-10$ years & 115 & 38.3 & 78 & 26 & & \\
\hline More than 10 years & 106 & 35.3 & 56 & 18.66 & & \\
\hline Age at onset of abuse & $17 \pm 5.5$ & - & - & - & - & - \\
\hline \multicolumn{7}{|l|}{ Cigarette smoking } \\
\hline No & 13 & 4.3 & 5 & 1.66 & & \\
\hline Yes less than $10 /$ day & 35 & 11.7 & 19 & 6.33 & 1 & $0.05^{*}$ \\
\hline Yes 10-20/day & 122 & 40.7 & 88 & 29.33 & & \\
\hline Yes more than $20 /$ day & 130 & 43.3 & 65 & 21.66 & & \\
\hline \multicolumn{7}{|l|}{ Shisha smoking } \\
\hline Yes & 148 & 49.3 & 94 & 31.33 & 2 & n.s. \\
\hline No & 152 & 50.7 & 83 & 27.66 & & \\
\hline
\end{tabular}


Table 3 Type, amount, and most common method of administration of the addictive drug used according to the AADIS (Adolescent Alcohol and Drug Involvement Scale) scale

\begin{tabular}{|c|c|c|c|c|}
\hline Type of drug & No. & $\%$ & $\begin{array}{l}\text { Amount taken according to AADIS } \\
\text { mean } \pm S D\end{array}$ & Most common method of administration \\
\hline Cannabis only (bango or hashish) & 20 & 6.66 & $23 \pm 5$ & Inhalation, ingestion \\
\hline Hallucinogens (LSD, MDMA, others) & 0 & 0.00 & - & - \\
\hline Alcohol only (beer, wine, liquor, or Buza) & 5 & 1.66 & $30 \pm 1$ & Oral \\
\hline Tramadol (synthetic opioids) only & 75 & 25 & $40 \pm 1$ & Oral \\
\hline Heroin only (or other opiates, opium, morphine) & 10 & 3.33 & $38 \pm 1$ & Ingestion, inhalation, injection \\
\hline Barbiturates only & 2 & 0.66 & $21 \pm 1$ & Oral \\
\hline Cocaine only (powder, coke, blow) & 4 & 1.33 & $39 \pm 1$ & Injection, inhalation \\
\hline Rock cocaine (crack, rock, freebase) & 2 & 0.66 & $38 \pm 1$ & Injection, inhalation \\
\hline Inhalants only (glue, gasoline, cans, whiteout, rush, others) & 2 & 0.66 & $40 \pm 1$ & Inhalation \\
\hline Valium, other tranquilizers & 3 & 1 & $25 \pm 1$ & Oral \\
\hline Amphetamines & 0 & 0 & - & - \\
\hline Others & 0 & 0 & - & - \\
\hline Mixed drugs & 177 & 59 & $45 \pm 8$ & \\
\hline
\end{tabular}

Table 2 shows sociodemographic characteristics of the studied patients and its relation with violence induced in the period of addiction. As observed from the table, significant difference among different age groups was noted $(p=0.05)$. The most affected age range is $21-30$ years old, the age of maximum power for work, followed by the age group 31-40 years. Regarding sex differences, a high significance was detected between both male and female genders where addiction was most prominent in Upper Egypt male patients than female patients. Educational level showed no significant difference among those who received university degree or those who were illiterate. Concerning marital status, occupation, and shisha smoking, no significant difference was observed. By comparing those who were victims of violence during their childhood and those who were not, a highly significant difference ( $p=0.001)$ was observed, where the percentage of violence reached $24.33 \%$. There was also a highly significant difference $(p=0.001)$ according to the duration of addiction. Violence increased among those with 5 to 10 years' addiction followed by those with more than 10 years of addiction, and there was a highly significant difference among those of cigarette smoking more than 20 cigarettes per day.
Table 3 shows the type of abused drug, doses according to AADIS (Adolescent Alcohol and Drug Involvement Scale), and the most common methods used by patients. Most of the patients used multiple drugs, followed by addiction to tramadol, a synthetic opioid that appeared in Egypt primarily as a drug for pain relief and later on as an addictive drug. According to the scale, the patterns of drugs used among patients were very high; the scale mean was 45 in mixed drug use. The table also shows that the use of hallucinogen, like LSD and MDMA, and amphetamines is not common among patients in Upper Egypt.

Table 4 shows the Modified Overt Aggression Scale (MOAS) scores in the period before and after addiction. It shows highly significant difference in all types of aggression (verbal aggression, physical aggression towards objects, towards self, and towards others), after addiction if compared by the period before addiction.

In Table 5, the relation between different types of addictive drugs among patients and the type of violence according to the MOAS is demonstrated. It appeared that cannabis abuse was more related to physical self-aggression; abuse of alcohol was more related to verbal and physical aggression towards others; tramadol

Table 4 Modified Overt Aggression Scale (MOAS) (Modified Overt Aggression Scale) in patients, before and after addiction

\begin{tabular}{llll}
\hline Modified Overt Aggression Scale (MOAS) & Before addiction & After addiction & $P$ value \\
\hline Verbal aggression & $0 \pm 1$ & $3 \pm 1$ & $0.001^{* *}$ \\
Physical aggression towards objects & $0 \pm 1$ & $3 \pm 1$ & $0.001^{* *}$ \\
Physical self-aggression (auto-aggression) & $0 \pm 1$ & $3 \pm 1$ & $0.001^{* *}$ \\
Physical aggression towards others & $0 \pm 1$ & $3 \pm 1$ & $0.001^{* *}$ \\
Total score & $0-10$ & $20-40$ & $0.001^{* *}$ \\
\hline
\end{tabular}

**P value is highly significant $\leq 0.001$ 
Table 5 Relation between type of drug of abuse and violence according to (MOAS)

\begin{tabular}{|c|c|c|c|c|c|}
\hline & Verbal aggression & $\begin{array}{l}\text { Physical aggression } \\
\text { towards objects }\end{array}$ & $\begin{array}{l}\text { Physical self- } \\
\text { aggression }\end{array}$ & $\begin{array}{l}\text { Physical aggression } \\
\text { towards others }\end{array}$ & $\begin{array}{l}\text { Total } \\
\text { scores }\end{array}$ \\
\hline & Mean $\pm S D$ & Mean \pm SD & Mean \pm SD & Mean \pm SD & $\begin{array}{l}\text { Mean } \pm \\
\text { SD }\end{array}$ \\
\hline Cannabis only (bango or hashish) & $2 \pm 1$ & $2 \pm 1$ & $3 \pm 1$ & $1 \pm 1$ & $13-25$ \\
\hline Hallucinogens (LSD, MDMA, others) & $\begin{array}{l}\text { Not present in the study } \\
\text { sample (N.P) }\end{array}$ & $(N . P)$ & $(N . P)$ & (N.P) & $(N . P)$ \\
\hline Alcohol only (beer, wine, liquor) & $3 \pm 1$ & $1 \pm 1$ & $1 \pm 1$ & $2 \pm 1$ & $11-26$ \\
\hline Tramadol (synthetic opioids) & $3 \pm 1$ & $3 \pm 1$ & $2 \pm 1$ & $3 \pm 1$ & $17-37$ \\
\hline $\begin{array}{l}\text { Heroin only (or other opiates, opium, } \\
\text { morphine) }\end{array}$ & $1 \pm 1$ & $1 \pm 1$ & $2 \pm 1$ & $3 \pm 1$ & $14-28$ \\
\hline Barbiturates only & $1 \pm 1$ & $1 \pm 1$ & $3 \pm 1$ & $1 \pm 1$ & $23-26$ \\
\hline Cocaine only (powder, coke, blow) & $1 \pm 1$ & $1 \pm 1$ & $2 \pm 1$ & $2 \pm 1$ & $17-27$ \\
\hline Rock cocaine (crack, rock, freebase) & $1 \pm 1$ & $1 \pm 1$ & $2 \pm 1$ & $2 \pm 1$ & $17-27$ \\
\hline $\begin{array}{l}\text { Inhalants only (glue, gasoline, cans, } \\
\text { whiteout, rush, others) }\end{array}$ & $3 \pm 1$ & $3 \pm 1$ & $2 \pm 1$ & $3 \pm 1$ & $17-37$ \\
\hline Valium, other tranquilizers & $1 \pm 1$ & $1 \pm 1$ & $1 \pm 1$ & $1 \pm 1$ & $10-20$ \\
\hline Amphetamines & (N.P) & (N.P) & (N.P) & (N.P) & (N.P) \\
\hline Others & (N.P) & (N.P) & (N.P) & (N.P) & (N.P) \\
\hline Mixed drugs & $3 \pm 1$ & $3 \pm 1$ & $3 \pm 1$ & $3 \pm 1$ & $20-40$ \\
\hline
\end{tabular}

was related more to verbal aggression, physical aggression towards objects, and aggression towards others; heroin was related to physical aggression towards others; cocaine (either powder or crack) was related to aggression towards self and others; inhalants were more related with the verbal aggression and aggression towards objects and towards others; and finally, in case of mixed drugs, all types of aggression can occur.

Table 6 shows the relation between drugs and the type of committed crime during the period of addiction. It appears crimes committed differ according to type of abused drug. Cannabis was mostly related to self-damage such as suicide, and tramadol was mostly related to making quarrels with friends and family as well as stealing from others to gain the drug. Cocaine and heroin were mostly related to sexual crime and selling drugs to gain money.

\section{Discussion}

The aim of this study is to assess the relationship between type of drug abuse and type of violence, to measure the degree of violence related to each type of drug abuse, and to clarify the patterns of drug abuse in Upper Egypt.

The sociodemographic data of abuse in Upper Egypt and its relation with violence shows male abuse was highly significant when compared with the female abuse. Age distribution of abuse was as follow: the most critical age was between 21 to 30 years old followed by 31 to 40 years old. The age of onset of drug abuse is so critical, at young age about 12 years old. There is a highly significant relation between being a previous victim and long period of addiction with occurrence of violence. There is no significant difference between the abuse among those of high education and those illiterate. There was no significant difference among those married, single, or divorced; among those living in rural or urban; and among those with occupation and those without occupation.

One of the main findings in this research is the change of the trends of abuse in Egypt from cannabis and its leaves (bango) to use the tramadol. Trends of drug abuse in Upper Egypt were cannabis mainly and its leaves (Yassa et al. 2009 and Yassa 2012). This is confirmed by Bassiony et al. (2015) who prove the idea that the tramadol began to be the gateway for drug abuse in Egypt. Wide availability of tramadol, its cheap price, and media appearance as a painkiller helped to introduce it widely among Egyptians (Fawzi 2011; Alsirafy et al. 2015; Bassiony et al. 2015).

World Health Organization detects that the number of tramadol abusers is growing especially in some Middle East countries (Zabihi et al. 2011; Taghaddosinejad et al. 2011; and Nazarzadeh et al. 2014). According to the AADIS, the scale of use of tramadol was $40 \pm 1$, which is a very high scale; this indicates the excessive use of tramadol by addicts in Upper Egypt.

Some studies have confirmed the opioid activity of oral tramadol but conclude that tramadol has a modest abuse liability and also mild withdrawal symptoms which resemble those occurring after cessation of serotonin-specific reuptake inhibitors (Woody et al. 2003; Epstein et al. 2006; and Radbruch et al. 2013). In this study, the abuse liability 


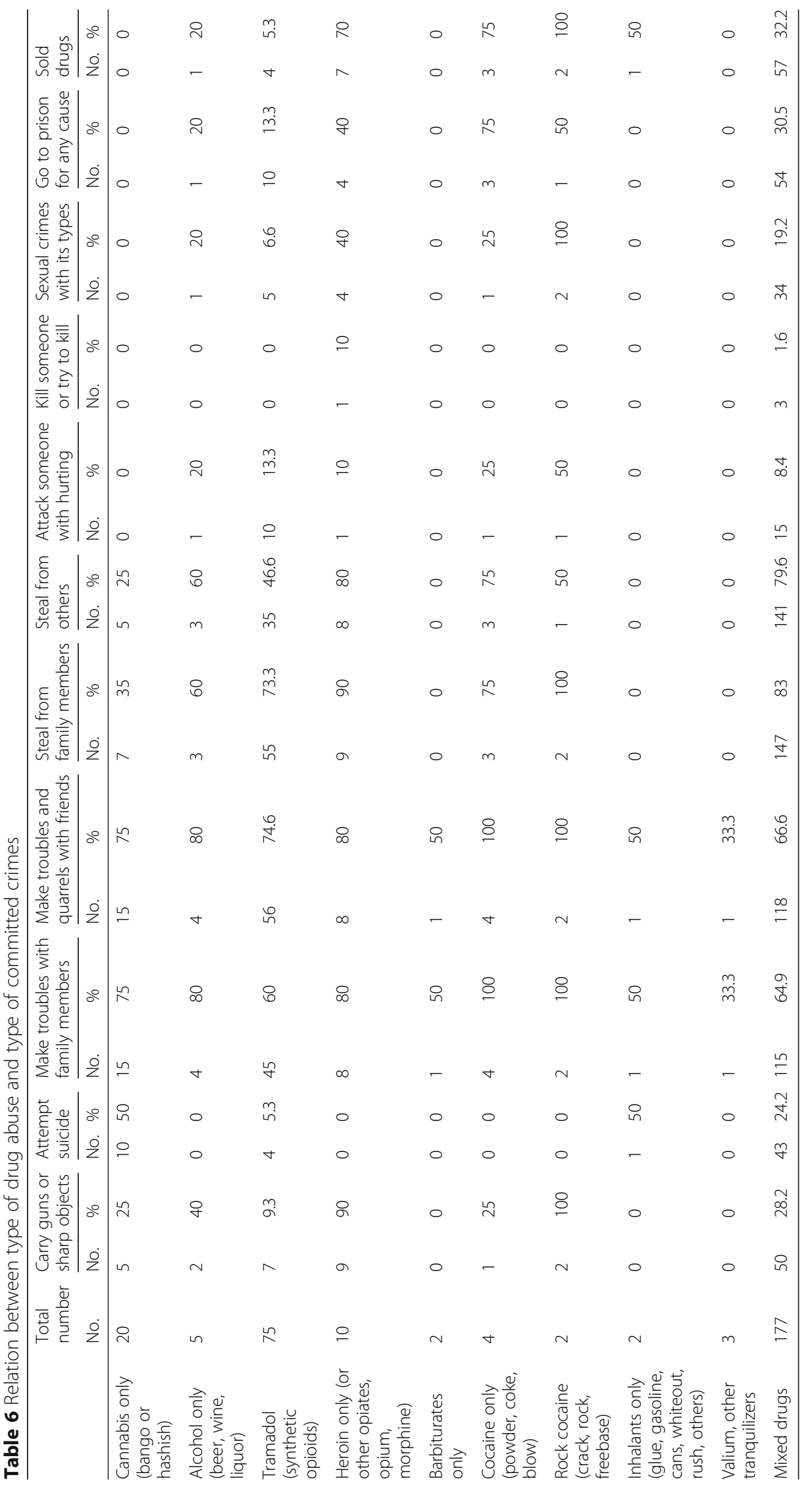


from the history of the patients is very high, the mostly used method is through oral administration, and the patients were in need to increase the dose, sometimes reaching 10 tablets $(225 \mathrm{mg}) /$ day, with severe withdrawal symptoms, which need hospitalization. A study done in China confirmed the result of this study as they concluded that tramadol has a clear risk of producing high abuse potential under the long-term infrequent abuse and high doses (Zhang and Liu 2013). According to the national report in Egypt, cannabis is the mostly misused substance; in this survey, they do not ask about tramadol directly as it is considered by most of adult as an analgesic and to treat the premature ejaculation (Hamdi et al. 2013 and Bassiony et al. 2015). According to the Egyptian law, tramadol is prevented to be sold in the pharmacy by using the common prescription, only by special prescription, as it is an abused drug since 2012, decision no. 125 for 2012 (http://cpegy. blogspot.com/2012/03/125-2012.html).

This study found a correlation between the violence and drug abuse. Violence is a result, and not a causative agent for addiction. The difference among the drug abuse is the type of violence. All types of violence can be found in mixed drugs addiction, self and verbal aggression is common with cannabis abuse, and aggression towards others is common in tramadol, opioids, heroin, and inhalants addiction. Auto-aggression is common in cannabis and barbiturates. Verbal aggression is common in cannabis, tramadol, and inhalants. Aggression towards objects is found in tramadol and inhalants addiction. The aggression towards others and towards objects clarifies the homicidal crimes that are committed against unknown persons.

Harris and Barraclough (1997), Borowsky et al. (2001), and Claro et al. (2015) found that all problems related to alcohol and other drug abuse are associated with psychiatric disorders, such as anxiety disorders, depression, attention deficit, conduct disorders, and hyperactivity disorders. This idea is supported by the finding of Yassa et al. (2010) that abuse of bango (cannabis leaves) affects the brain cells through shrinkage and increases the fatty cell. According to Ghoneim et al. (2014), tramadol affects the brain cells in the form of apoptosis, which can be explained by elevation of lipid peroxidation products with the inhibition of antioxidant enzyme gene. Chronic exposure to thinners or inhalants produces oxidative stress in the brain and increases the free radicals process and the glutathione peroxidase activities, which affect the brain cells (Burmistrov et al. 2001; Martinez-Alfaro et al. 2011 and Martínez-Alfaro et al. 2010).

Chermack et al. (2010) and Paim Kessler et al. (2012) prove the relation between cocaine, either crack or powder, and alcohol with the partner violence.
In contrast to this study, Gorman and White (1995) in their study prove that there are subcultural norms, which increase what is called the street behaviors. These norms lead to the criminal behaviors and addiction. However, in this study, the statistics of crime increase with the same individual after addiction if compared with the period before addiction. Nurco (1998) confirmed that in their study, they noted that the individual crime rates increase six times after addiction.

This study found that there was a significant relation between the history of patients during childhood, either due to abuse or as a stress disorders. This agrees with Swogger et al. (2011); Barrett et al. (2011) and Lev-Ran et al. (2012) who prove that childhood abuse, attention deficiency, and posttraumatic disorders are considered as risk factors for addiction that lead them to violence.

\section{Conclusion}

In conclusion, drug abuse is an important risk factor for all types of violence. The risk of inflicted wounds either homicide or suicide was increased in the community due to the increase in the abused drugs. Types and degree of violence differ according to the type of drug abuse.

\section{Recommendations}

Good treatment and rehabilitation of the addicts and abusers is a step towards reducing the rate of crimes in our area and also decreasing the number of psychiatric patients. Protection of the public from those addicts can be done only by treating and re-integrating them into the community, not by avoiding them. Forensic psychiatry can develop this balance between those patients and community protection.

\section{Additional files}

Additional file 1: Annex 1: Adolescent Alcohol and Drug Involvement Scale (AADIS) according to (Moberg and Hahn's, 1991). (DOCX 26 kb)

Additional file 2: Annex 2: The Modified Overt Aggression Scale (MOAS) (Kay et al., 1988). (DOCX $21 \mathrm{~kb}$ )

Additional file 3: Annex 3: Questionnaire for drug abuse and crime relation. (DOCX $24 \mathrm{~kb}$ )

\section{Abbreviations}

AADIS: Adolescent Alcohol and Drug Involvement Scale; DSM: Diagnostic and Statistical manual of Mental Disorders; HPLC: High-performance liquid chromatography; MOAS: Modified Overt Aggression Scale; NIH: National Institute of Health

\section{Acknowledgements}

Special thanks to Assiut Hospital of Psychiatry, all staff members. They help as much as they can to facilitate our interviews with patients.

Funding

The research had no fund from any agency.

Availability of data and materials

Please contact author for data requests. 


\section{Authors' contributions}

HAY contributed in the idea of the research, made the questionnaires and ensured their validity, meet the patients, wrote the research with the statistics. STB validated the questionnaire, meet the patients, and revised the manuscript. Both authors read and approved the final manuscript.

\section{Ethics approval and consent to participate}

Ethical approval was taken from the "General Secretariat of Mental Health and Addiction Treatment, Ministry of Health, Egypt" it can be available at the need.

Consent from patients also taken before the beginning of the research.

\section{Consent for publication}

The research paper did not contain any videos or personal data.

\section{Competing interests}

The authors declare that they have no competing interests.

\section{Publisher's Note}

Springer Nature remains neutral with regard to jurisdictional claims in published maps and institutional affiliations.

\section{Author details}

${ }^{1}$ Forensic Medicine and Clinical Toxicology Department, Assiut University, Asyut, Egypt. ${ }^{2}$ Assiut Psychiatric Hospital, Asyut, Egypt.

Received: 19 October 2018 Accepted: 6 March 2019

Published online: 30 March 2019

\section{References}

Alsirafy S, Saleh R, Fawzy R, Alnagar A, Hammad A, El Sherief W, Farag D, Radwan $R$ (2015) The fear of using tramadol for pain control (tramadolophobia) among Egyptian patients with cancer. J Opioid Manag 11(6):474-480

Barrett EL, Mills KL, Teesson M (2011) Hurt people who hurt people: violence amongst individuals with comorbid substance use disorder and posttraumatic stress disorder. Addict Behav 36:721-728. https://doi.org/10.1016/j. addbeh.2011.02.005

Bassiony M, Salah El-Deen G, Yousef U, Raya Y, Abdel-Ghani M, El-Gohari H, Atwa $S$ (2015) Adolescent tramadol use and abuse in Egypt. Am J Drug Alcohol Abuse 41(3):206-211. https://doi.org/10.3109/00952990.2015.1014959

Boles S, Miotto K (2003) Substance abuse and violence: a review of the literature. Aggress Violent Behav 8:155-174. https://doi.org/10.1016/S13591789(01)00057-X

Borowsky IW, Ireland M, Resnick MD (2001) Adolescent suicide attempts: risks and protectors. Pediatrics 107(3):485-493

Burmistrov SO, Arutyunyan AV, Stepanov MG, Oparina TI, Prokopenko VM (2001) Effect of chronic inhalation of toluene and dioxane on activity of free radical processes in rat ovaries and brain. Bull Exp Biol Med 132:832-836. https://doi. org/10.1023/A:101310631

Chermack ST, Grogan-Kaylor A, Perron BE et al (2010) Violence among men and women in substance use disorder treatment: a multilevel event-based analysis. Drug Alcohol Depend 112(3):194-200. https://doi.org/10.1016/j. drugalcdep.2010.06.005

Claro H, Oliveira M, Bourdreaux J, Fernandes I, Pinho P, Tarifa R (2015) Drug use, mental health and problems related to crime and violence aross sectional study. Rev Latino Am Enfermagem 23(6):1173-1180. https://doi.org/10.1590/ 0104-1169.0478.2663

Epstein DH, Preston KL, Jasinski DR (2006) Abuse liability, behavioral pharmacology, and physical-dependence potential of opioids in humans and laboratory animals: lessons from tramadol. Biol Psychol 73(1):90-99. https:// doi.org/10.1016/j.biopsycho.2006.01.010

Fawzi MM (2011) Some medicolegal aspects concerning tramadol abuse: the new Middle East youth plague 2010. An Egyptian overview. Egypt J Forensic Sci 1:99-102

Federal Register (FR) (2017) Mandatory guidelines for federal workplace drug testing programs, vol 82, p 13

Feldkamp CS (2010) Immunological reactions. In: Kaplan LA, Pesce AJ (eds) Clinical chemistry: theory, analysis, and correlation. Mosby, St. Louis, pp 151-179

Ghoneim F, Khalaf H, Elsamanoudy A, Helaly A (2014) Effect of chronic usage of tramadol on motor cerebral cortex and testicular tissues of adult male albino rats and the effect of its withdrawal: histological, immunohistochemical and biochemical study. Int J Clin Exp Pathol 7(11):7323-7341

Gorman DM, White HR (1995) You can choose your friends, but do they choose your crime? Implications of differential association theories for crime prevention policy. In: Barlow H (ed) Criminology and public policy: putting theory to work. Westview Press, Boulder

Hamdi E, Gawad T, Khoweiled A, Sidrak AE, Amer D, Mamdouh R, Fathi H, Loza N (2013) Lifetime prevalence of alcohol and substance abuse in Egypt: a community survey. Subst Abus 34:97-114. https://doi.org/10.1080/08897077. 2012.677752

Hamdi E, Sabry N, Sedrak A, Khowailed A, Loza N (2016) Sociodemographic Indicators for Substance Use and Abuse in Egypt. J Addiction Prevention. 4(1):8

Harris EC, Barraclough B (1997) Suicide as an outcome for mental disorders. A meta-analysis. Br J Psychiatry 170(3):205-228

Ilgen M (2011) The link between substance abuse, violence and suicide. Psychiatr Times 28(1):1-7

Kay SR, Wolkenfelf F, Murrill LM (1988) Profiles of aggression among psychiatric patients: I. Nature and prevalence. J Nerv Ment Dis 176:539-546

Lev-Ran S, Aviram A, Braw Y et al (2012) Clinical correlates of cannabis use among adolescent psychiatric inpatients. Eur Psychiatry 27:470-475. https:// doi.org/10.1016/j.eurpsy.2011.11.002

Martínez-Alfaro M, Cárabez-Trejo A, Gallegos-Corona MA, Pedraza-Aboytes G, Hernández-Chan NG, Leo-Amador GE (2010) Thinner inhalation effects on oxidative stress and DNA repair in a rat model of abuse. J Appl Toxicol 30(3): 226-232. https://doi.org/10.1002/jat.1488

Martinez-Alfaro M, Contreras Y, Carabez-Trejo A, Leo-Amador G (2011) Oxidative stress effects of thinner inhalation. Indian J Occup Environ Med 15(3):87-92. https://doi.org/10.4103/0019-5278.93195

Meyer AL, Cohen R, Edmonds T, Masho S (2008) Developing a comprehensive approach to youth violence prevention in a small city. Am J Prev Med 34(3 Suppl):S13-S20. https://doi.org/10.1016/.j.amepre.2007.12.006

Moberg, Hahn (1991) Adolescent drug involvement scale. J Adolesc Chem Depend 2:75-88

Moller KE, Lee KC, Kissack JC (2008) Urine drug screening: practical guide for clinicians. Mayo Clin Proc 83(1):66-76. https://doi.org/10.4065/83.1.66

National Institute of Drug Abuse (2017): The science of drug abuse and addiction. https://www.drugabuse.gov/ publications /media-guide/sciencedrug-abuse-addiction-basics

Nazarzadeh M, Bidel Z, Carson KV (2014) The association between tramadol hydrochloride misuse and other substances use in an adolescent population: phase I of a prospective survey. Addict Behav 39(1):333-337. https://doi.org/ 10.1016/j.addbeh.2013.09.013

Nurco DN (1998) A long-term program of research on drug use and crime. Subst Use Misuse 33:1817-1837. https://doi.org/10.3109/10826089809059323

Paim Kessler FH, Barbosa Terra M, Faller S et al (2012) Crack users show high rates of antisocial personality disorder, engagement in illegal activities and other psychosocial problems. Am J Addict 21:370-380. https://doi.org/10. 1111/j.1521-0391.2012.00245.x

Qureshi N, Al Ghamdy Y, Al Habeeb T (2000) Drug addiction: a general review of new concepts and future challenges. East Mediterr Health J 6(4):723-734

Radbruch L, Glaeske G, Grond S, Munchberg F, Scherbaum N, Storz E, Tholen K, Zagermann-Muncke P, Zieglgansberger W, Hoffmann-Menzel H, Greve H, Cremer-Schaeffer P (2013) Topical review on the abuse and misuse potential of tramadol and tilidine in Germany. Subst Abus 34(3):313-320. https://doi. org/10.1080/08897077.2012.735216

Rakhawy YT, Ewaida M, El-Kott S, Faheem A, Abdulwahab MM, et al. (1996) The General Secretariat of Mental Health- MOH: The National Research on Addiction (use, abuse, dependency and addiction) preliminary report, $\mathrm{MOH}$

Swogger MT, Conner KR, Walsh Z, Maisto SA (2011) Childhood abuse and harmful substance use among criminal offenders. Addict Behav 36:12051212. https://doi.org/10.1016/j.addbeh.2011.07.025

Taghaddosinejad F, Mehrpour O, Afshari R, Seghatoleslami A, Abdollahi M, Dart RC (2011) Factors related to seizure in tramadol poisoning and its blood concentration. J Med Toxicol 7(3):183-188. https://doi.org/10.1007/s13181-011-0168-0

Tiet QQ, Ilgen MA, Byrnes HF, Moos RH (2006) Suicide attempts among substance use disorder patients: an initial step toward a decision tree for suicide management. Alcohol Clin Exp Res 30:998-1005. https://doi.org/10. 1111/j.1530-02777.2006.00114.x

Woody GE, Senay EC, Geller A, Adams EH, Inciardi JA, Schnoll S, Munoz A, Cicero TJ (2003) An independent assessment of MEDWatch reporting for 
abuse/dependence and withdrawal from Ultram (tramadol hydrochloride). Drug Alcohol Depend 72(2):163-168. https://doi.org/10. 1016/S0376-8716(03)00198-4

World Drug Report (2017) United Nations Office on drugs and crime. http:// www.unodc.org/unodc/en/frontpage/2017/June/world-drug-report-2017_29-5-million-people-globally-suffer-from-druguse-disorders--opioids-the-mostharmful.html

World Health Organization (2002): World report on violence and health World Health Organization (2014a): Expert committee on drug dependence, thirty sixth meeting, Geneva 16-20 June 2014

World Health Organization (2014b): Global status report on violence prevention 2014

Wu AHB (2001) Urine adulteration before testing for drugs of abuse. In: Shaw LC, Kwong TC, Rosano TG, Orsolak PJ, Wolf BA, Magnani B (eds) The clinical toxicology laboratory: contemporary practice of poisoning evaluation. American Association for Clinical Chemistry, Inc., Washington, DC, pp 157-171

Yassa H, Dawood A, Shehata M, Abdel Hady R, Abdel Aal K (2010) Subchronic toxicity of cannabis leaves on male albino rats. Hum Exp Toxicol 29(1). https://doi.org/10.1177/0960327109354312

Yassa H, Dawood A, Shehata M, Abdelhady R, Abdel Aal K (2009) Risk factors for bango abuse in Upper Egypt. Environ Toxicol Pharmacol 28(3):397-402. https://doi.org/10.1016/j.etap.2009.07.003

Yassa HA (2012) Bango abuse in upper Egypt. LAP LAMBERT Academic Publishing, Cannabis ISBN-13: 978-3-8484-8706-6

Zabihi E, Hoseinzaadeh A, Emami M, Mardani M, Mahmoud B, Akbar MA (2011) Potential for tramadol abuse by patients visiting pharmacies in Northern Iran. Subst Abuse 5:11-15. https://doi.org/10.4137/SART.S6174

Zhang H, Liu Z (2013) The investigation of tramadol dependence with no history of substance abuse: a cross-sectional survey of spontaneously reported cases in Guangzhou City, China. Biomed Res Int 2013:283425. https://doi.org/10. $1155 / 2013 / 283425$

\section{Submit your manuscript to a SpringerOpen ${ }^{\circ}$ journal and benefit from:}

- Convenient online submission

- Rigorous peer review

- Open access: articles freely available online

- High visibility within the field

- Retaining the copyright to your article

Submit your next manuscript at $\boldsymbol{\nabla}$ springeropen.com 